\title{
Transforming universities in interactive digital platform: case of city university of science and information technology
}

\author{
Muhammad Nauman Habib ${ }^{1}$ (D) - Waseef Jamal ${ }^{2}$ • Uzma Khalil ${ }^{3}$. \\ Zunnoorain Khan ${ }^{1}$
}

Received: 3 February 2020 / Accepted: 21 May 2020 / Published online: 10 July 2020

(C) Springer Science+Business Media, LLC, part of Springer Nature 2020

\begin{abstract}
The purpose of this research was to understand the automation of Higher Education Institutes (HEIs), and to evaluate the automated process from the perspective of developing country. A single case study of City University of Science and Information Technology (CUSIT), Pakistan was selected as a unit of analysis. Mix methodology was used in this research. Semi-structured in-depth interviews were conducted from the top management as a primary source while secondary data regarding usage and functions of LMS was collected for the period of 2 years (four semesters Fall-2017-Spring 2019). Data from both sources was utilized, and triangulated for case building and analysis. It was found that CUSIT has a state-of-the-art automated infrastructure, management information system (MIS) and learning management system (LMS) which facilitates faculty, staff and administration. LMS provides an integrated and digital platform to key stakeholders particularly to the teachers for sharing course outlines, lesson plan, assignment generation and submission, announcements and generating assessment reports. Similarly, the student gets access to all course material, assignments, assessment report, notices, and other relevant information at any point of time. However, the system lacks some of the major E-learning features with limited support to the large file size, real time learning, online classes, real time feedback and query system etc. Furthermore, this study identified few seldomly used functions of automated system as well as few duplications and operational activities which requires consideration by the management. The case of CUSIT proves to be a practical case for all those universities who are facing challenges due to corona virus pandemic and are looking for a solution to continue education through distance learning and e-learning platforms. This study supports the automation of HEIs and provides lesson learned for the academia and management of HEIs by identification of success features as well as limitations of the system.
\end{abstract}

Keywords Automation · Management information system · E-learning · Case study · Learning management system

Muhammad Nauman Habib

habib_nauman@hotmail.com

Extended author information available on the last page of the article 


\section{Introduction and background of the study}

Information and Communication Technology (ICT) has exerted its influence on almost every field of life which has metamorphosed different aspects of these fields. The impact of ICT in the era of digitalization, globalization and in the age of information is evident in higher education (Wheeler 2001). Particularly, the use of internet and dependency on digital gadgets has transformed the learning and knowledge sharing approaches (Arkorful and Abaidoo 2015; Sarkar 2012). ICT has not only revolutionized and transformed the classroom learning and teaching methods, but also mutated distance learning programs, leading to reshaped libraries as well as accessibility towards learning materials (Farid et al. 2015). Thus, persistent upgradation of technology aided the access to the digital world of information (Soomro et al. 2018). Hence, the digital world has beneficial accessibility information to different fields.

As Higher Education Institutes (HEIs) generate and disseminate knowledge, therefore an integrated and technology driven system becomes effectively instrumental in learning and exercising research activities. Hence, from this standpoint, ICT serves as an appropriate and significant tool for HEIs in knowledge creation and dissemination (Altamony et al. 2012). Besides teaching and research, there are several interdependent and interrelated activities that pillars simultaneously in HEIs, for example: semester planning, course allocation, course enrollment, course design, timetable, research allocation and supervision, examination planning, paper setting, results, assignments, quiz management, fee management, classroom allocation, dealing with probation students, workload management, aligning program objectives, course objectives and so on (Tolley \& Shulruf 2009). For essentially stable and successful academic programs, the aforementioned activities, play a crucial role. Substantially, the focus is on automation of libraries in universities (Sani \& Tiamiyu 2005), whereas, numerous other cointegrated and correlated activities that are taking place simultaneously are ignored. Traditional approach which is mainly focused on manual activities are considered to be non-interactive, therefore, However, ICT enabled systems can prove to uphold ameliorated coordination between faculty, students and administration which may, for its part, help HEIs (Agbatogun 2013).

Since the last four decades, there has been tremendous change in education, teaching, and methodology. Computer technologies have forced the higher education providing bodies to bring radical change in their approaches. Certain factors are believed to be propelling agents in HEIs adaptation of ICT which can thus be exhibited through different tools. Those factors include adaptation of latest technologies, interactive learning environment, increase in the use of internet, and availability of online resources (Mostert and Quinn 2009). However, Education Management Information System (EMIS), Learning Management System (LMS), ICT enabled classrooms and campuses, and e-learning are the tools that are transforming HEIs in developed as well as developing countries (Kukulska-Hulme and Traxler 2007). According to Capper (2003), these integrated technologies have been found constructive to support the academicians in the form of content areas, support students in learning key skills (e.g. communication, analytical, collaboration, and creativity etc.), and help in creating bridge between teacher, student, and management. More Significantly, it has no negative impact on the quality of education, quite the contrary, it has provided assistance in improving the skills of faculty and students (Wabwoba et al. 2011). Thus, 
the emerging technologies are bringing efficiency, effectiveness, remote accessibility, alignment, flexibility, and access to information with ease and comfort, consequently, attracting HEIs in developed and developing states.

Developed as well as developing world's HEIs are showing growth in ICT driven initiatives for improving quality of education and becoming more efficient and effective (Agbatogun 2013; Amassoma et al. 2010). Anshari et al. (2016) claim that the online availability of learning activities is providing extended learning opportunities to students as well as faculty members. Pertaining to above mentioned tools, Browne et al. (2006) through statistical calculation reported that 95\% of HEIs in United Kingdom are utilizing LMS and ICT. This alludes to the fact of growing trust and utility in the ICT driven academic activities. Henceforth, Mostert and Quinn (2009) believe that ICT is a solution to the most of academic problems in this era of globalization. However, Gibbone et al. (2010) reported that teachers are reluctant to use integrated technologies into their learning and teaching methods. Predominantly, literature suggests that students are quick learners and adopts technology very quickly (Barak et al. 2006; Kukulska-Hulme and Traxler 2007; Patterson and Patterson 2017) as compared to the teaching staff (Hennessy et al. 2005; Ruthven and Hennessy 2002; Sanders and George 2017). Some of the identified reasons embedded in faculty's reluctance are lack of skills, training, status-quo, lack of motivation, lack of time, lack of confidence, increase in workload, lack of experience, and lack of attitude (Mukama and Andersson 2008; Mwalongo 2012; Rezaei and Meshkatian 2017). The need for LMS, e-learning, and distance education has become an integral part of continuity of higher education due to outbreak of Covid19. Despite the lack of readiness and resources, universities has realized the need for alternative and technology driven platforms to continue the learning process.

Despite the odds, there is an increase in the number of HEIs and also in the use of ICT driven education systems. In Pakistan, the number of degree awarding universities/ HEIs has increased tremendously. As per record of Higher Education Commission (HEC) of Pakistan, there are 195 recognized degree awarding universities/HEIs in Pakistan (HEC 2019). Out of which, 79 are private sector universities/HEIs. The increasing number of private sector universities/HEIs shows the level of trust on the quality of education provided by private sector (Rizwan et al. 2016). Pertaining to this fact, similar trend of increasing student enrollment in private sector HEIs has been reported in literature as well (Agarwal 2007; Altbach 1999; Halai 2013; Tierney \& Sirat 2008). However, despite increase in HEIs, there are several issues prevailing in higher education in Pakistan. Some of the major impediments faced by higher education in Pakistan are lack of qualified faculty, outdated curriculum, student's motivation, lack of government spending, access to quality education, low literacy rate, lack of focus on knowledge economy, lack of employment opportunities, and lack of financial resources (Aziz et al. 2014; Farid et al. 2015; Qureshi et al. 2012).

The spheres of concern related to private sector universities in Pakistan are highlighted by Qureshi et al. (2012), which are; technical limitations, access to computers, English language competencies, dependency of students on their instructors for learning, level of awareness, resistance to change, and privacy issues. E-learning has not gained much popularity in Pakistan, however, owing to multiplying rate of the private sector HEIs, there are signs favoring improvement in learning through ICT (Khan 2007). Moreover, Rizwan et al. (2016) identified five major areas for improving 
quality of education in private sector of Pakistan: physical facilities, academics, learning outcomes, responsiveness, and personality development are the factors that has enhanced enrolment in private sector universities.

Literature is limited towards causes of success and failure, digital library, perception of students and teachers towards LMS and ICT. The quality of education is key to success and ICT is playing its role. Thus, there is still a substantial need for improvement and advancements in the private sector HEIs of Pakistan (Farid et al. 2015). In the current scenario of social distancing, classroom teaching has become impossible to achieve due to lockdown. All HEIs, extensively rely on the traditional face-to-face teaching and classroom methodology; therefore, the traditional teaching cannot be completely substituted by the ICT based systems. Hence, it raises the concerns regarding the features and activities offered by the ICT systems of those HEIs. However, literature has limited to offer on why, in the first place, ICT based systems are adopted and what are the features (both limiting and supportive) of ICT based system that can contribute in substituting traditional face to face teaching to cope with the continuation of education cycle in the pandemic outbreak of Covid19.Thus, the purpose of this study is to evaluate and understand the purpose of adopting state-of-theart technology and transformation from manual to ICT driven system. This study aims to study the effectiveness of ICT driven LMS and its applicability in continuing higher education in the state of lockdown due to Covid19. Thus, it is important to investigate the case of digital campus with functional LMS with the objective to evaluate the features of LMS and technology so that the HEIs can utilize the functional areas and adopt the ICT driven module for uninterrupted education during the pandemic outbreak.

To answer the research questions and to achieve the objectives of this research, a case study of City University of Science and Information Technology (CUSIT), Peshawar, Pakistan has been adopted for investigation. CUSIT is a chartered and degree awarding private sector university, established in 2001 as an extension of Peshawar Model Educational Institutes (PEMI) established in 1979, and is the largest education system of Khyber Pakhtunkhwa (KP), Pakistan. CUSIT aims to provide quality education at affordable cost in the discipline of Management Sciences, Computer Sciences, Engineering, Health Sciences, Education, Architecture, English, and Mathematics. In the constraints of the mentioned discipline, the programs offered ranges from undergraduate to post-graduate level. Within short span of time, however expeditiously, CUSIT has attained phenomenal position and produced over 4000 graduates and at present over 2000 students are enrolled into various programs and disciplines. CUSIT introduced its own developed MIS in 2004-2005 which enabled all the academic departments, administration and classroom to integrate over a digital platform. Attendance of employees was also digitalized initially using fingerprint, Numpad, and subsequently, optimized with addition of Radio Frequency Identification (RFID) cards. RFID cards are used by faculty, staff and students for their campus attendance as well as classroom attendance, hence sustaining a contribution in monitoring all academic activities, decision making, and reporting activities. In 2017-2018, CUSIT developed an online tool called City University Learning Management System (CULMS). This digital tool provide support to the faculty and students to impart knowledge in the form of learning material and to meet the requirements of Outcome Based Education (OBE). 


\section{Research methodology}

A case study-based approach was adopted to gain in-depth insight of the knowledge and experiences. The real-life context was important part of the study to examine the details, complexities, purpose and objectives, and insight into the various activities associated with LMS. In regard to input through respondents, every individual contributes a rich insight and every word said has sense within. It is ideal for such research because it provides rich insight of the topic under investigation. A single case study, in this reference, aids in understanding the whole phenomenon in-depth by engaging both researcher and respondents. Through case study method, a researcher is enabled to use a variety of research methods of social sciences to reach to the core of complex outcome that has been narrated by the respondents. Many researchers and scholars have used case study in their research and doctoral dissertations (see for example; Almeida et al. 2000; Agyepong and Adjei 2008; Fu 2012; Gourley 2009; Soni 2000; Uddin and Tsamenyi 2005). Yin (2003) also supports the choice of single case for indepth investigation. Moreover, Baxter and Jack (2008) also support the single case with embedded units for research. In order to have compendious and wide-ranging understanding of the subject, data was collected from both primary and secondary sources. For primary data, semi-structured in-depth interviews were conducted adopting purposive sampling technique. In this type of sampling, also called judgement sampling, the participants are knowingly selected on the basis of the qualities possessed by the participants (Etikan et al. 2016). This includes the subjects exclusively well informed about the phenomenon under study as well as are able to communicate the experiences and ideas efficiently without any hesitation (Tongco 2007). Semi-structured in-depth interviews were conducted from the employees who were directly or indirectly part of management and involved in the transformation process. According to Creswell (2013), for the phenomenological (interpretive) approach, the ideal sample size is five (5) to twenty-five (25). As this study is focused on single case study, therefore, the sample of six respondents from top management and IT section were sufficient to reach to the saturation point. The studies with modest claims might accomplish saturation sooner as compared to the studies that aim at broader group and comprehensive ideas (Charmaz 2008). Right after the interviews, official documents, memos and meeting minutes were examined. Moreover, the real time data was extracted from the server to understand the process of LMS and its utilization. Triangulation of method helped in nullifying the lack of validity in the study (Cohen et al. 2013). Data was triangulated to develop a case study and present findings into meaningful manner. Triangulation was used to facilitate research design. Interviews were transcribed and memos were generated (using qualitative research techniques). Manual coding process was adopted using NVivo 12. Automatic coding categories generated by NVivo were not consistent with the nature of this study, therefore, manual approach was used to generate nodes and coding. For the presentation of data, thematic networking diagram was used. In presenting thematic analysis, this tool can be helpful and provides further support in presenting the findings in a network shape which is easy to understand. Themes are identified and presented in three layers i.e. basic, organizing, and global themes (Habib et al. 2019). Thus, the whole categories of codes and thematic networking for presenting an in-depth detailed case. According to Nowell et al. (2017), thematic networking is widely used technique for the presentation of qualitative data into more formal and 
comprehensive manner. The information extracted from interviews was merged with the data collected from secondary source and later triangulated, tabulated and presented in the results and findings section.

\section{Results and findings}

\subsection{Why CUSIT adopted digitalization and LMS?}

Digital platforms (such as: MIS and LMS) are the most powerful tools for any management activity. It eases the monitoring process at every level like academic starting form class teacher or lecture, head of the department and coming to the administrative positions like registrar and VC. Based on this, it makes it easy for us to make the decisions. Moreover, there are three fundamental aspects of any HEI i.e. to provide security, ensure discipline and provide academics. These fundamental aspects of HEI is fulfilled through digital solutions. The digitalization brings efficiency and effectiveness into the overall monitoring and decision-making process. Moreover, the coding indicated transparency as one of the objectives in establishing ICT system. All the activities can be easily monitored along with the date and time of the activity which makes things more explicit. Furthermore, it makes academic activities more disciplined, as the LMS and MIS keeps the record of data in sequence which can be searched with one click. Moreover, the data is stored in the backup which can be reused for different reasons. Overall, the purpose and objectives of LMS and IMS is to move towards automation, ease to monitor, ease of decision, transparency, real-time information, security, going paperless, academic improvements and establishing discipline (refer to Fig. 1). However, all the stated objectives overlap and aid one another.

LMS and MIS are created to assist the students in smooth functioning of educational activities. The coding revealed that students can use LMS for with their individual identity numbers from where they can login. Moreover, students can access learning material, timetable, fee information, notifications, results and assessments on LMS. In addition, students can also place their queries and applications on the system (see Fig. 1). Hence, this shows that students activities are maintained through LMS extensively.

Multiple functions were reported by the participants from teaching staff for which LMS and MIS are utilized. Coding demonstrated that it is used to access timetable, memo, attendance record, academics and students' list. Moreover, it serves to make announcements, allows sign in and sign out from the class and campus, and permits uploading lectures, materials, assessments and evaluation (see Fig. 1). In addition to that, all the data uploaded is saved in the file server which is easily accessible from any workstation and classroom PCs on campus.

The overall features identified by all the participants include E-memo, attendance, customized reporting, fee and accounts, learning material, admission and student service, timetable allocation, digital results, digital library, academic activities and reporting, administrational activities, application and record, course outlines and digital classrooms (refer to Fig. 1). Thus, through digitalization, data is secured, discipline is maintained, and it provides grounds for learning and knowledge as well. CULMS and MIS are the need-based software that were developed inhouse however, considering the need of the time, it was incumbent for the system to evolve and upgrade. Computer and 


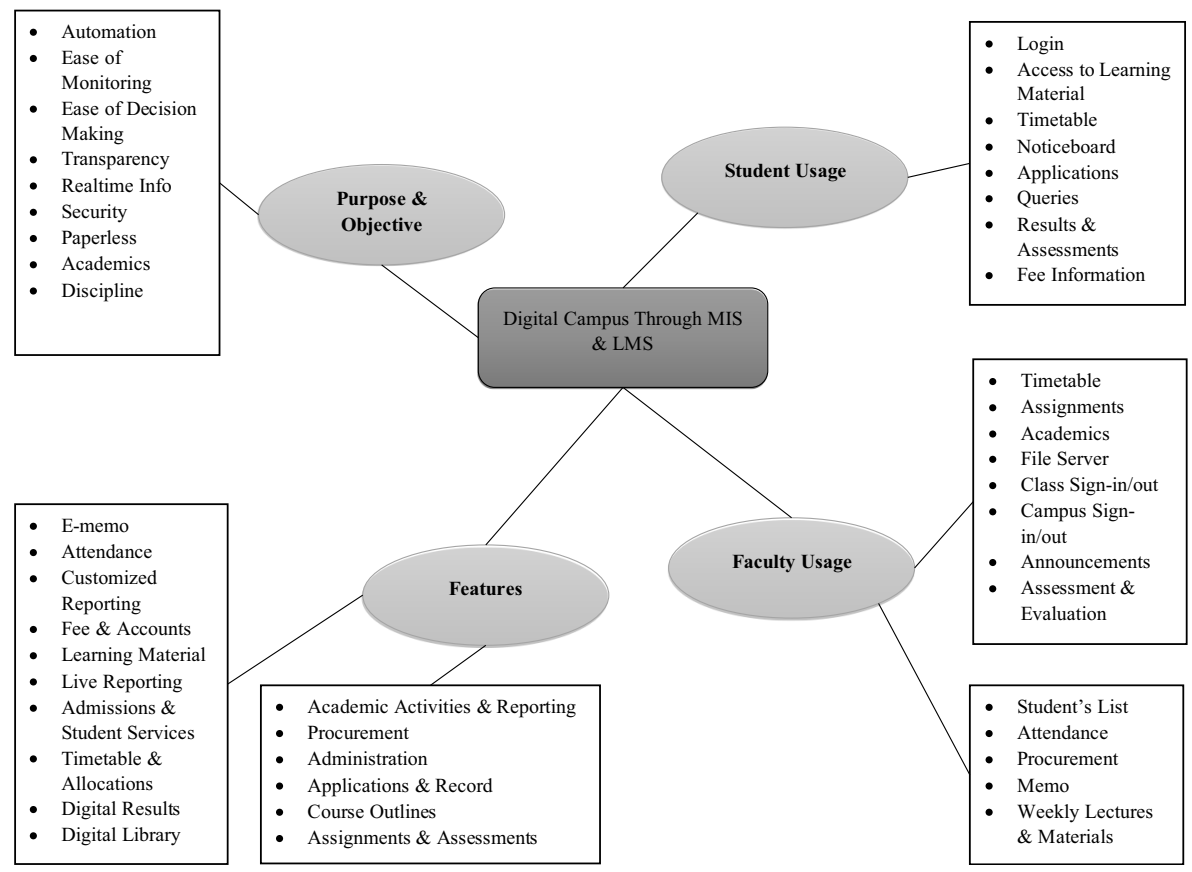

Fig. 1 Thematic network

technology are used to make systems yield more efficacious processing and results. Moreover, it helps in integrating the whole system including teaching, management, administration, learning activities and so on. Even though, the automated system is well in place and meets the requirements, yet, it is tenaciously evolving and improving in conformity with the changing requirements of modern era education. Hence, all the above-mentioned features highlighted through coding are the reasons to initiate automated system in order to facilitate the education system and to go paperless. However, one of the important participants reported regarding the use of system that "Although, we want to make it 100 percent, however, there are some constraints and limitations ... we would have been completely paperless organization".

Concerning the understanding and working of system, some of the salient features and roles of MIS are discussed below.

To promote culture of paperless environment, all internal memos and notifications are sent using MIS, thereby helping in improving efficiency and effectiveness of dissemination of information. Moreover, it has enabled CUSIT for becoming environment friendly organization which validates its social responsibility towards environment. All staff members have access to trancieve, that is both sending a memo and receiving one. In pursuance of facilitation in the process, the system is devised to provide the sender with different options; the sender can choose the receivers either by name (individually), department-wise (as a whole) or the entire university. Unique identification numbers are assigned to each memo (for record purpose) with an option to attach file. At the receiving end, after viewing the memo, an automatic 
acknowledgment is displayed with the option to reply as well as forwarding the memo. As memos are connected to the official emails as well as SMS system, therefore, a receiver and sender get the alert by their registered mobile number as well as receive a copy of memo through their official email concurrently.

\subsection{Salient features and roles of digital infrastructure}

The CUSIT campus has been automated and all functional areas/support sections are linked through a digital infrastructure. The linkage and digital platform is presented in Fig. 2. While each of the salient feature and roles within are explained below.

\subsubsection{Role of admission and student services}

Students enrolled in CUSIT are registered through MIS by the admission section in their respective programs and departments. The admission numbers are autogenerated and assigned in sequential order. Furthermore, biodata and previous academic record is entered against unique student ID. Once students are assigned with registration numbers, Student Services Officer (SSO) registers the students in courses offered in their first semester. The record is being updated and admission fee along with all academic and administrative dues are synchronized with Accounts section. Students deposit their fee with the in-campus bank branch which has access to the system. Immediately after the fee is deposited, the system is updated and accessible to SSO office and other departments for subsequent processing. Once registration process is completed, the SSO office provides them with a computer-generated timetable along with details of subjects, instructor and location of the assigned class. The same data is synced with the server which enables IT department to generate password for students' account to be used for logging in into computers in any computer laboratory along with the access to the LMS of CUSIT. Moreover, the same information is synced with admin department for printing RFID equipped student cards. As MIS is operational and utilized in every

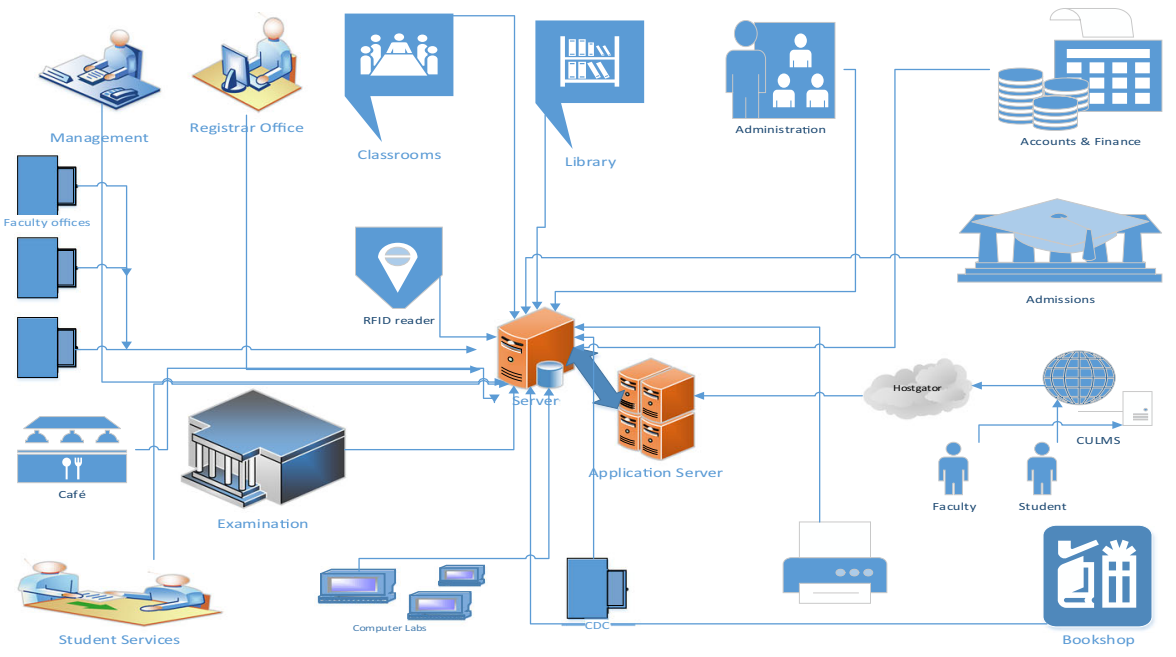

Fig. 2 Automated CUSIT campus 
department of CUSIT, therefore, student's ID is used both by students as well as staff for services, for example: Library, accounts, academic department, examination, bookshop, registrar section, IT and so on.

Student Services Officer enters list of assigned subjects to every batch of each program into system and register different batches of the programs for the subjects sent from the concern coordinators of each academic department. Simultaneously, teachers are also registered against subjects sent by academic department. MIS generates an automated timetable as per the tentative academic calendar. The system is linked to the examination where students' result is allied to the promotion into next semester and accordingly, to generate list of scholarships. After the completion of registration process, student's dues and fee are generated once again, following the same procedure as mentioned above for the next semester. In case of probation students (less than 2 GPA), their report is generated and shared with academic departments as well as with the student's counselling center. Thus, enabling integration and co-integration of all stakeholders in the process. MIS helps in registering courses, batch promotion, semester wise subject and teacher allocation, fee record, scholarships, student clearance, prerequisite courses details, makeup classes arrangement, removing any clashes in timetable, and other facilitation required by academic departments and students. Thus, semester planning is done with ease, efficiency and effectiveness through MIS.

\subsubsection{Role of library management system}

Along with other systems and departments, the library of CUSIT is also digitalized through MIS. All the customary functions performed in libraries thorough manual system are automated in CUSIT's library; Book issuance, renewal of books issued, return and reservation of book is done through MIS. Library Management System can search the record of books by subject, title, authors' name, publisher and keywords. Moreover, it has the capacity to keep record of accompanying material (CD and access key etc.). It also keeps record of the library staff who makes entry into system which can be counter checked for accountability purpose. A separate record is maintained within the MIS to keep record and history of books issued to students and employees.

\subsubsection{Role of academic head and coordinator of department}

Head of the Department (HoD) and departments' coordinators play key role in academic activities. MIS helps academic heads in semester planning, subject allocation, teacher allocation, grants access to student's biodata, access to department's timetable, employee's on campus attendance, class attendance, student's attendance, SMS to students, result, makeup classes, contact hours report, MCQs bank, and all relevant academic reports e.g. record of probation students, short attendance report, events, prerequisite, memo etc. These facilities are provided to departments for quick decision making, monitoring, and for efficiency purpose.

\subsubsection{Role of faculty}

Faculty is enabled to send requisition to bookshop, check contact hours report, attendance report, send receive and reply to memos, see timetable, request makeup 
classes, upload course outlines, student evaluation, send attendance (in-case of some technical issue with network), develop MCQ bank for subjects assigned, fill course evaluation and teacher evaluation surveys.

\subsubsection{Role of registrar office}

Registrar section is the central office in any university which regulates approximately all functions of university. MIS facilitates registrar office in several ways: Generating admin reports, batch-wise reports, requisitions, registered courses information, fee record, attendance report of employees and students, examination record, courses exemptions, memo, program transfer requests by students, scholarships, semesters and registered courses, students' clearance, student information, short attendance, faculty reports, timetable report, issuance of warning letters, access to personnel files, new enrollment and alumni record, SMS to students and staff, and other relevant activities.

\subsubsection{Role of examination}

The responsibilities of examination unit in university is to administer examination, secrecy, result preparation and declaration of result, and issuance of transcripts and degrees. MIS, for examination section of CUSIT, is instrumental in keeping student and exam record, program transfer, issuance of provisional certificates, transcript, degree, preparation of award-list, update degree status, gazette, paper attempts, exam schedule, students' status, courses transfer, employee record, fee status, student biodata, memo, requisition, attendance report, and registered courses etc. Almost all examination activities are streamlined through MIS except paper setting and record of question papers due to the secrecy issues.

\subsubsection{Role of administration}

Administration section of CUSIT can generate admin reports, requisition and memo, as well as can access registered courses report, student's details, batch-wise report, fee record, scholarships, student's attendance, student biodata, warning letters, employee's attendance report, SMS to students, session report, transport, and timetable report. This information is essential for providing facilities and liaison support to other department, therefore, MIS helps admin department to perform their duties efficiently and effectively.

\subsubsection{Role of accounts and finance}

Accounts and Finance section utilizes MIS for requisition, memo, view registered courses, student's details, vouchers, employee salary, account summary, account entry, students' fee, payroll, fee refund, student payments, and transport purposes. Although these are few functions of accounts and finance section of CUSIT, where the rest of activities are performed separately.

\subsubsection{Role of career development center}

Career Development Center (CDC) is an integral part of CUSIT which helps in student's and alumnus' placement. The roles assigned to CDC through MIS includes 
requisition, registered courses' information, memo, student's attendance, student biodata, and Alumni data.

\subsection{Limitations and constraints in MIS of CUSIT}

Besides the efficacious utility of automated system, there are certain limitations of this system. Firstly, as a part of academics, the semester planning (including subject and teacher allocation) is very important activity. The HoD/Coordinator of academic department performs the semester planning activity manually. Although the data of subjects studied in previous semesters in provided by the MIS, yet this activity requires manual effort. The semester planning data is shared with SSO officer via memo, who as a succeeding process, enters the list of subjects, assigned teachers and registered students through MIS. Secondly, there is a function of maintaining and updating employee's record electronically via MIS, however, this function is not yet optimized completely. Thirdly, as the examination section plans to conduct examination (mid and final-term) with the help of MIS, therefore, in order to assign invigilation duties, the request for invigilators is send via memo. Since the data is already available in the system, therefore, this manual work is interpolated in the automated process. Furthermore, the MIS supports student's evaluation (marks entry) of sessional marks (midterm, major and minor assignment/test/quizzes etc.) and the final-term marks are not entered through MIS. This results in laborious task for both faculty and examination section. Fourthly, there is a feature of course outline uploading in the MIS, however, this function is rarely used. Faculty prefers to share the course outline in soft using lecture drive (common faculty folder which is accessible in classrooms), however, in the other case, it is uploaded through CULMS. Fifthly, MIS is equipped with the function to develop MCQs bank for each subject, aiming to set up class tests etc., is a rarely utilized function. Sixthly, classroom attendance system was converted from attendance marked by the teacher in the software during the class to RFID based system. The teacher arriving at the class signed in through his/her card and student's attendance was marked via same mechanism. However, after implantation, this system was rolled back due to several issues. The President of CUSIT shared his views regarding this aspect as follows;

I wasn't thinking that we will have to do that but before rolling back the teachers and students were consulted, and they gave very valid reasons. There was disturbance in the class and the students who used to come late to the class used to mark themselves present and teachers control over the students was losing. Like teachers make the students sit in the class or ask them to answer by using this attendance. They were using it as a stick and I was glad that there are teachers who are using all possible means to hold students and make them work.

Seventhly, there are few limitations due to which paperless system cannot be ensured. For instance, there are some requirements of external bodies which require evidence in the hard form;

There are few documents we have to have written application of students for HEC and legal documents. I know it is meaningless but from now onwards we 
will scan papers and go paperless. Change is always difficult... We are trying to go paperless in Fall 2019.

Eighthly, there are specific office holders added to almost every memo sent, for example: registrar, head of the departments and sections, PS to President, and VC etc., thus, it becomes very difficult for them to read and respond to every memo sent. Moreover, the memo system is connected with official email as well as it is notified via SMS which increases the fatigue of employees.

Ninthly, MIS has no specific role defined for the Quality Enhancement Cell (QEC), pertinent to the fact that this department inhibits very important function in the modern era. The QEC staff requests IT, registrar office or other departments for required data, thus, it is duplication of efforts and labor.

Thus, taking into account the positive aspects of MIS, to utilize the e-learning tools, CUSIT introduced its own Learning Management System (LMS) as an online integrated platform to take advantage of internet technology.

\subsection{City university learning management system (CULMS)}

In Fall-2017 session, CUSIT launched its online LMS as a part of promoting Outcome Base Education (OBE). The primary purpose was to provide e-learning platform and to meet the requirements of PEC. Every academic department developed its vision, mission, program educational objectives (PEOs), program learning outcomes (PLOs), and course learning outcomes (CLOs). Thus, assessing students on Bloom's Taxonomy and continuous assessment required a separate system. Hence, CULMS was developed to meet these requirements and take advantage of ICT. An online system was designed (inhouse) by engaging external host (hostgator) and was connected to the internal server using Wide Area Network (WAN).

CULMS has two major end users i.e. faculty and students. Login to CULMS is through their respective IDs and Passwords. CULMS provides a platform for courses taught by respective faculty, access to their timetable, applications from students, students' attendance entry and OBE. It provides facets which enables the faculty to design course outline, insert the CLOs and map them to PLOs. Moreover, faculty can assign CLOs to topics of each teaching week and upload supporting/reading material as per delivery plan. Furthermore, there is a facility to conduct assessment of each CLO and evaluate the performance of every individual student. For the purpose of evaluation, a faculty member can choose from a list of activities e.g. quiz, class test, assignment, presentation, group discussion or any other method of evaluation. Each course exhibit certain options which are concatenated with the others: enrolled students, assignment, evaluation, lectures, course outline, attendance, internal evaluation and announcements. Every course contains a list of students enrolled in the specific subject. An instructor can add assignment in the description box through a feature available to annex files, if required, as well as announce deadline. There is a separate option to assess the performance of students under probation and to set student's counselling hours for each semester. Since Fall-2017, faculty shared 8608 teaching material as a source of e-learning, 1002 assignments were uploaded and 2052 times student's performance was assessed (see Fig. 3). The system provides an option of evaluation of different weeks/teaching material against which the faculty is required to upload 


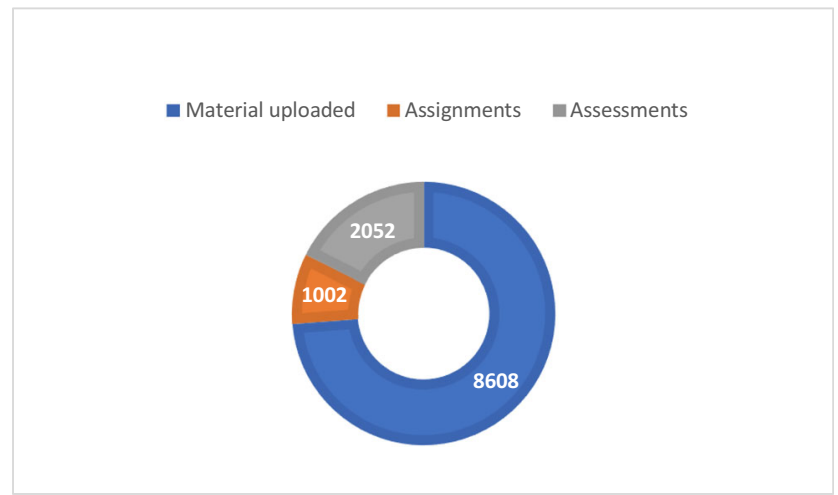

Fig. 3 Usage of CULMS e-learning and assessment

assessments. This reflects that the teaching material uploaded is not analogous to the assessments. Hence, this key feature of assessments against each week is not utilized by the teachers. Moreover, it ascertains the use of other means of evaluation apart from assignments.

There are evidences of increase in the use of CULMS by faculty, however, the trend varies from department to department. As shown in Fig. 3, the data collected from session Fall-2017 to Fall-2018, there is an increase in the utility with respect to elearning material, assignments uploading and online student's assessment. However, this trend is not improving in every academic department. The positive feature of CULMS is course outlines and the weekly lecture plan which are completely uploaded and updated by every department. Hence, it can be ascertained that the educational field of teaching staff may affect the use of technology. Therefore, trainings predicated on departments' performance can be initiated to ensure better use of CULMS Fig. 4.

Students are able to access their respective course material remotely, check their results and transcripts, stay up-to-date with the announcements, upload their assignments, check their timetables, fee, submission of an application concerning any department, keep record of their relevant report, fill course evaluation and teacher

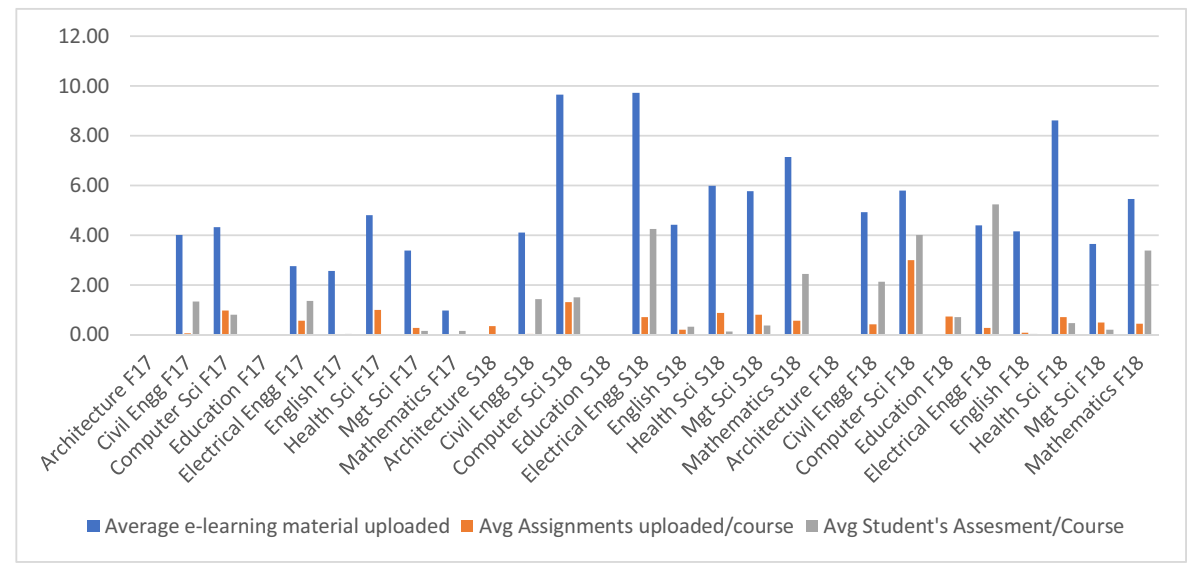

Fig. 4 Average usage of CULMS by department 
evaluation forms by the end of semester. Student's applications are entertained only if they are submitted using CULMS. This helped in reducing paper wastage as well as quick response to the registered applications. Moreover, the online application system has enabled the management to keep track of applications and also to keep in repository for record (see Fig. 5).

Thus, pertaining to the aforementioned capabilities, CULMS ensures timely dissemination of information, learning materials and other relevant activities that are useful for learning and knowledge sharing purpose. However, the use of CULMS still requires attention. As indicated earlier, the progress of few departments is below average which adversely affects the objectives of automation and purpose of e-learning. Overall, the system has capacity to be utilized. The unique feature of CULMS is linkage to the OBE system which provides access to both faculty and students from everywhere. Hence, one of the shortcomings of MIS was its permittance of access which was solely allowed from on-campus systems, however, this limitation has been resolved recently. CULMS has provided a ground for enchanting learning opportunities through digital platform. Figure 5 provides a complete list of functions and activities available to students, faculty and head of departments, which can be adopted by others while implementing their own systems. The functions and activities of CULMS are majorly divided in three loops: Teachers, head of the department or coordinator, and students. The teachers have access to further three sections: applications, my courses and finalized courses. The finalized courses are previously taught courses which are retained in the repository along with all the details intact from the time it was the part of 'my course'. The details of activities are mentioned in Fig. 5 against 'my courses' and 'finalized courses'. Moreover, head of departments and coordinators have access to similar features as teacher, with addition to some activities: teacher course, contact hours, teacher course review, students' information, students' email, students' counselling and probation students. Furthermore, the students have access to twenty-three (23) different functions mentioned against 'student' in Fig. 5.

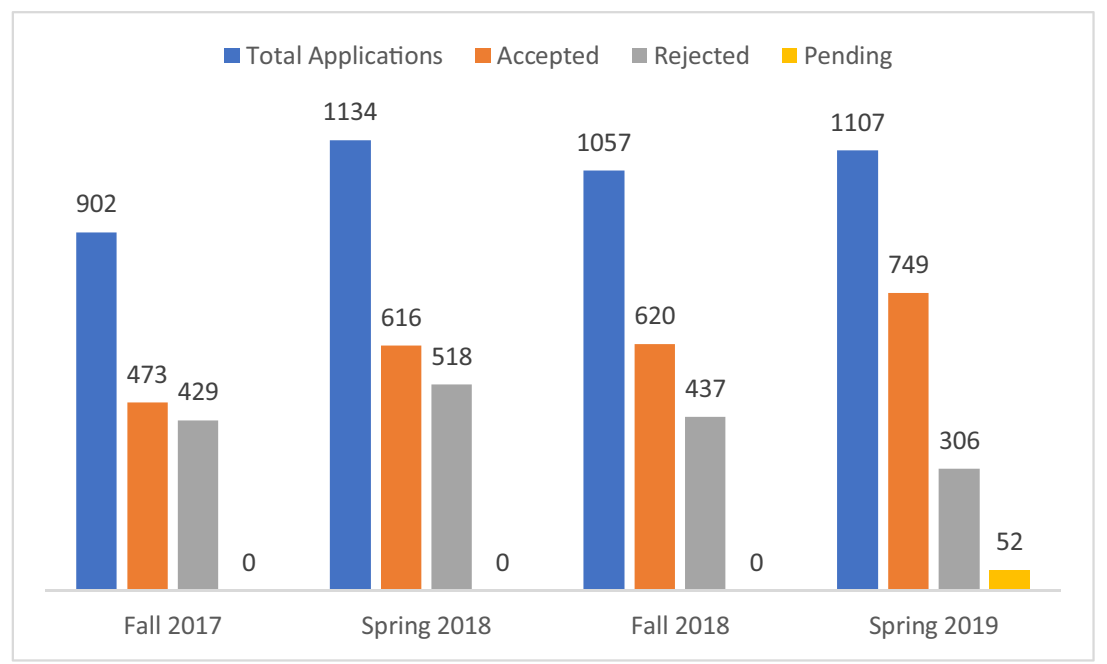

Fig. 5 Student's application status session-wise 
In addition to the utility of CULMS by faculty and Students, it is used by Administration, Quality Enhancement Cell (QEC), SSO, and general staff. Allocated functions of these sections are mentioned in Fig. 6. All the functions and activities of nonteaching sections are divided in four loops: Admin, QEC, SSO and general staff application. Admin has availability of twenty-two (22) different functions in CULMS, which are stated collectively in Fig. 6. However, QEC has access to seven (7) functions, whereas, SSO has availability of ten (10) different commands (for detailed reference of the functions, see Fig. 6).

Information technology department of CUSIT was requested to generate the information pertaining to the available functions and features of CULMS. These feature and functions available to each stakeholder is presented in Table 1 and separately elaborated in Figs. 6 and 7. These figures and table provide a summary of elaborated results and findings in the above section.

\section{Discussion}

A substantial increase, worldwide, is observed in the adaptation of ICT enabled technologies in higher education (Al-Busaidi \& Al-Shihi 2010). It is evident from the case of CUSIT that ICT, as a reliable assistance, can be used in HEIs. Digital classrooms, MIS, CULMS and the local network of CUSIT has improved the productivity, efficiency, quality, teaching, management and learning process. This shows the growing trust of technology and utility of ICT in higher education. Literature has revealed several benefits of the use of ICT and e-learning in the higher education i.e. access to information and learning material, integration, cost reduction, knowledge sharing, and deep learning (Qureshi et al. 2012). Moreover, Barron (2003) mentioned three trends that results in adaptation of automation in HEIs are; flexibility of course management, availability of content, and proven research on utility of ICT in academia. In case of CUSIT, these above stated advantages were evident, indicating that HEIs are utilizing ICT for efficiency and effectiveness. Besides the positivity of ICT and its benefits, literature has reported several issues pertaining to developing countries; technical difficulties, computer literacy, resistance to change, student assistance, privacy and security, English proficiency, face-to-face interaction etc.(Bakari et al. 2005; Sife et al. 2007; Sweeney et al. 2004). In the light of factors identified in literature, CUSIT's automation does not show any signs of technical issues, computer literacy, resistance to change, however, student's assistance was lacking as there were no evidences of student's training on LMS. However, it was reported that students take informal assistance from their classmates and seniors. Moreover, privacy and security are ensured at CUSIT. According to Ssekakubo et al. (2011), developing countries are not successful in automation, e-learning and LMS supported initiatives. However, in the case of CUSIT, these initiatives are highly effective and useful. Hence, relatively asserting the above statements, the automated system of CUSIT has overcome the discrepancies identified by the literature at large by augmentation and rectification in the system.

City University within the first 5 years were able to introduce MIS and additional decade to launch the LMS. Over the years, there has been increase in the utilization of technology. As reported, almost $90 \%$ of all systems are digitalized in CUSIT. However, 
Table 1 MIS functions and reports available to key stakeholders

\begin{tabular}{|c|c|c|c|c|c|c|c|c|c|}
\hline & Registrar & Examination & $\mathrm{SSO}$ & Faculty & $\begin{array}{l}\text { HoD/ } \\
\text { Coordinator }\end{array}$ & Library & $\begin{array}{l}\text { Accounts } \\
\& \\
\text { Finance }\end{array}$ & Admin & $\mathrm{CDC}$ \\
\hline Admin report & $\mathrm{x}$ & & $\mathrm{X}$ & & & & & $\mathrm{x}$ & \\
\hline $\begin{array}{l}\text { Batch-wise } \\
\text { report }\end{array}$ & $\mathrm{x}$ & & $\mathrm{X}$ & & & & & $\mathrm{x}$ & \\
\hline Requisition & $\mathrm{x}$ & $\mathrm{x}$ & $\mathrm{X}$ & $\mathrm{x}$ & $\mathrm{X}$ & $\mathrm{x}$ & $\mathrm{x}$ & $\mathrm{x}$ & $\mathrm{x}$ \\
\hline $\begin{array}{l}\text { Reg. courses } \\
\text { info }\end{array}$ & $\mathrm{x}$ & & & & & & & & $\mathrm{x}$ \\
\hline Fee record & $\mathrm{x}$ & $\mathrm{x}$ & $\mathrm{X}$ & & & & & $\mathrm{x}$ & \\
\hline $\begin{array}{l}\text { Attendance } \\
\text { report }\end{array}$ & $\mathrm{x}$ & & & $\mathrm{x}$ & & & & & \\
\hline Courses system & $\mathrm{x}$ & & & & & & & & \\
\hline Exam record & $\mathrm{x}$ & $\mathrm{x}$ & & & & & & & \\
\hline Exempt courses & $\mathrm{x}$ & & $\mathrm{X}$ & & & & & & \\
\hline Memo & $\mathrm{x}$ & $\mathrm{x}$ & $\mathrm{X}$ & $\mathrm{x}$ & $\mathrm{x}$ & $\mathrm{x}$ & $\mathrm{x}$ & $\mathrm{x}$ & $\mathrm{x}$ \\
\hline $\begin{array}{l}\text { Program } \\
\text { transfer }\end{array}$ & $\mathrm{x}$ & $\mathrm{x}$ & & & & & & & \\
\hline Scholarships & $\mathrm{x}$ & & $\mathrm{X}$ & & & & & $\mathrm{x}$ & \\
\hline $\begin{array}{l}\text { Semester } \\
\text { courses }\end{array}$ & $\mathrm{x}$ & $\mathrm{x}$ & $\mathrm{X}$ & & $\mathrm{x}$ & & & & \\
\hline $\begin{array}{l}\text { Registered } \\
\text { courses }\end{array}$ & $\mathrm{x}$ & $\mathrm{x}$ & & $\mathrm{x}$ & & & $\mathrm{x}$ & $\mathrm{x}$ & \\
\hline $\begin{array}{l}\text { Student } \\
\text { attendance }\end{array}$ & $\mathrm{x}$ & $\mathrm{x}$ & $\mathrm{X}$ & & & & & $\mathrm{x}$ & $\mathrm{x}$ \\
\hline $\begin{array}{l}\text { Student } \\
\text { clearance }\end{array}$ & $\mathrm{x}$ & & $\mathrm{X}$ & & & & & & \\
\hline Student biodata & $\mathrm{x}$ & $\mathrm{x}$ & & & $\mathrm{x}$ & & & $\mathrm{x}$ & $\mathrm{x}$ \\
\hline $\begin{array}{l}\text { Short } \\
\text { attendance }\end{array}$ & $\mathrm{x}$ & & & & & & & & \\
\hline Faculty report & $\mathrm{x}$ & & & & & & & & \\
\hline Teacher/subject & $\mathrm{x}$ & & & & & & & & \\
\hline Timetable & $\mathrm{x}$ & & & $\mathrm{x}$ & $\mathrm{x}$ & & & & \\
\hline Warning letter & $\mathrm{x}$ & & & & & & & $\mathrm{x}$ & \\
\hline Personnel file & $\mathrm{x}$ & & & & & & & & \\
\hline Admissions & $\mathrm{x}$ & & & & & & & & \\
\hline Alumni data & $\mathrm{x}$ & & & & & & & & $\mathrm{x}$ \\
\hline Certificate & $\mathrm{x}$ & & & & & & & & \\
\hline $\begin{array}{l}\text { Contact hour } \\
\text { report }\end{array}$ & $\mathrm{x}$ & & & $\mathrm{x}$ & & & & & \\
\hline $\begin{array}{l}\text { Employee } \\
\text { attendance }\end{array}$ & $\mathrm{x}$ & & & & $\mathrm{x}$ & & & $\mathrm{x}$ & \\
\hline Convocation & $\mathrm{x}$ & & & & & & & & \\
\hline SMS students & $\mathrm{x}$ & & & & $\mathrm{x}$ & & & $\mathrm{x}$ & \\
\hline $\begin{array}{l}\text { Provisional } \\
\text { certificate }\end{array}$ & & $\mathrm{x}$ & & & & & & & \\
\hline
\end{tabular}


Table 1 (continued)

$\begin{array}{lllll}\text { Registrar Examination } & \text { SSO Faculty } & \begin{array}{l}\mathrm{HoD} / \\ \text { Coordinator }\end{array} & \text { Library } & \text { Accounts } \\ & & \& & \text { Admin CDC } \\ & & & \text { Finance } & \end{array}$

\begin{tabular}{|c|c|c|c|c|c|c|}
\hline Degree & $\mathrm{x}$ & & & & & \\
\hline Transcript & $\mathrm{x}$ & & & & & \\
\hline Award list & $\mathrm{x}$ & & & & & \\
\hline Pre-requisites & & $\mathrm{X}$ & & $\mathrm{x}$ & & \\
\hline Degree status & $\mathrm{x}$ & & & & & \\
\hline Gazette & $\mathrm{x}$ & & & & & \\
\hline $\begin{array}{l}\text { Marks } \\
\quad \text { evaluation }\end{array}$ & $\mathrm{x}$ & & & $\mathrm{x}$ & & \\
\hline Paper attempt & $\mathrm{x}$ & & & & & \\
\hline Exam schedule & $\mathrm{x}$ & & & & & \\
\hline Students status & $\mathrm{x}$ & & & & & \\
\hline Courses transfer & $\mathrm{x}$ & & & & & \\
\hline $\begin{array}{l}\text { Employee } \\
\text { record }\end{array}$ & $\mathrm{x}$ & & & & & \\
\hline $\begin{array}{c}\text { Batch intake } \\
\text { duration }\end{array}$ & & $\mathrm{X}$ & & & & \\
\hline $\begin{array}{l}\text { Courses } \\
\quad \text { registration }\end{array}$ & & $\mathrm{X}$ & & & & \\
\hline Semester plan & & $\mathrm{X}$ & & & & \\
\hline Make up classes & & $\mathrm{X}$ & $\mathrm{x}$ & $\mathrm{x}$ & & \\
\hline $\begin{array}{l}\text { New } \\
\text { batch/ } \\
\text { semester }\end{array}$ & & $\mathrm{X}$ & & & & \\
\hline $\begin{array}{l}\text { Courses } \\
\text { allocation }\end{array}$ & & $\mathrm{X}$ & & & & \\
\hline $\begin{array}{l}\text { Teacher } \\
\text { allocation }\end{array}$ & & $\mathrm{X}$ & & & & \\
\hline $\begin{array}{l}\text { Section-wise } \\
\text { students }\end{array}$ & & $\mathrm{X}$ & & & & \\
\hline $\begin{array}{l}\text { Semester-wise } \\
\text { students }\end{array}$ & & $\mathrm{X}$ & & & & \\
\hline Students clash & & $\mathrm{X}$ & & & & \\
\hline Tour/trip & & $\mathrm{X}$ & & & & \\
\hline Course outline & & & $\mathrm{x}$ & $\mathrm{x}$ & & \\
\hline $\begin{array}{l}\text { Students } \\
\text { evaluation }\end{array}$ & & & $\mathrm{x}$ & & & \\
\hline $\begin{array}{l}\text { Manual } \\
\text { attendance }\end{array}$ & & & $\mathrm{x}$ & $\mathrm{x}$ & & \\
\hline MCQ bank & & & $\mathrm{x}$ & $\mathrm{x}$ & & \\
\hline Student detail & & & $\mathrm{x}$ & $\mathrm{x}$ & $\mathrm{x}$ & $\mathrm{x}$ \\
\hline $\begin{array}{l}\text { All academic } \\
\text { report }\end{array}$ & & & & $\mathrm{x}$ & & \\
\hline $\begin{array}{l}\text { New semester } \\
\text { courses }\end{array}$ & & & & $\mathrm{x}$ & & \\
\hline
\end{tabular}


Table 1 (continued)

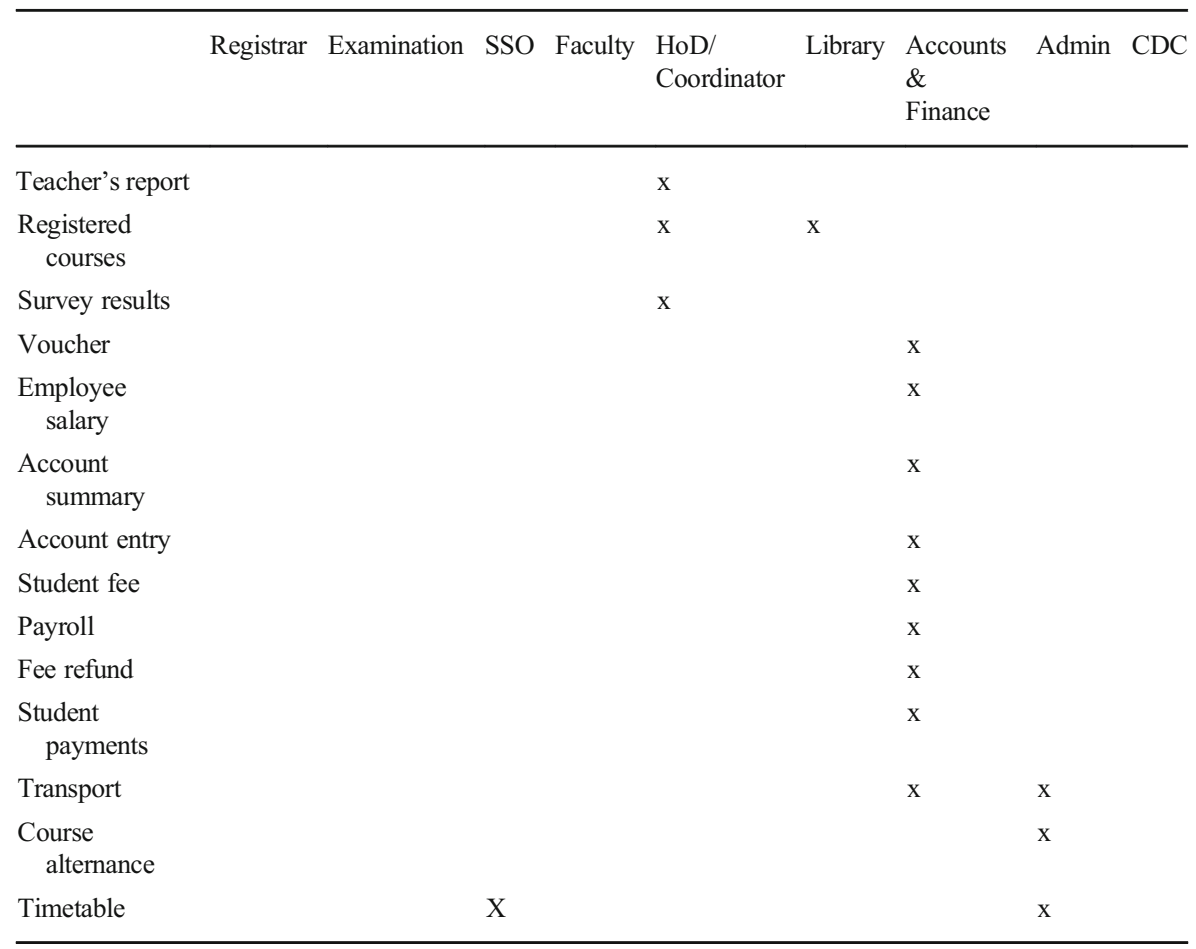

there are several features of MIS and LMS that are not utilized. These results are consistent with the previous researches (Rhode et al. 2017), however, there is little or no consensus among the researches. As Sani and Tiamiyu (2005) reported only 40\% utility of the available features of automated system in Nigeria, however, Rhode et al. (2017) reported increasing trend of utility and usage.

Similarly, Farid et al. (2015) identified critical issues in automation in Pakistani HEIs; software, technical, personal, institution, and cultural aspects. Software issues were not evident in CUSIT's case as it does not exhibit any inadequacy in design, quality or security. Similarly, technical issues are not evident as well i.e. there is a power backup, UPS system, proper internet and networking, and whole campus is WiFi zone. Personal factor may be considered as interest of faculty, staff and students in the use of ICT which varies from person to person. However, the personal factor may include the background of each individual, which entails age, proficiency and affiliation with specific field of study. On this premise, it can be argued that the knowledge of certain field of study has led to accumulated performance of specific department. Institutional dimension is not applicable in this case, due to purpose-built infrastructure, availability of enough resources, and top management commitment toward automation and utilization of ICT in CUSIT. Whereas, cultural dimension was not focused in this research, therefore, there are no evidences available to discuss cultural issues. Soomro et al. (2018) also acknowledges that faculty and students in Pakistan's HEIs are equipped with the technical knowledge and skills required for utilizing ICT. However, 


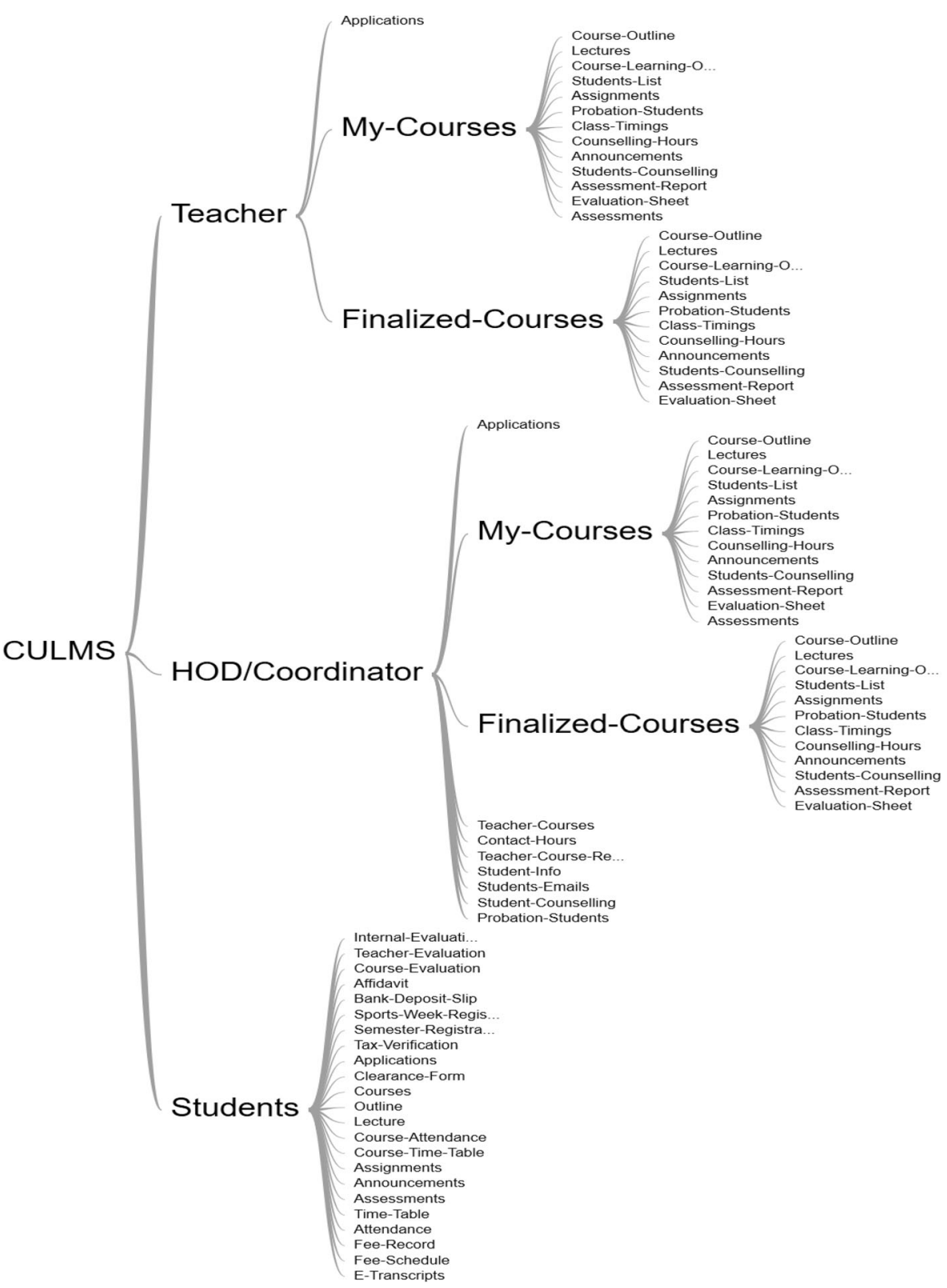

Fig. 6 Role of Teacher, Student and Department in CULMS

there is still a great deal to be done to increase the productivity, efficiency and effectiveness of digital technology and its utilization in HEIs.

The Covid19 pandemic posed a serious threat and raised a question mark on the traditional classroom teaching methodology. As a result, all sectors (including education sector) are shutdown till unknown time period. However, the HEIs are encouraged to continue education through online system or distance learning. During the pandemic lockdown, it is important that HEIs continue to provide quality education using 


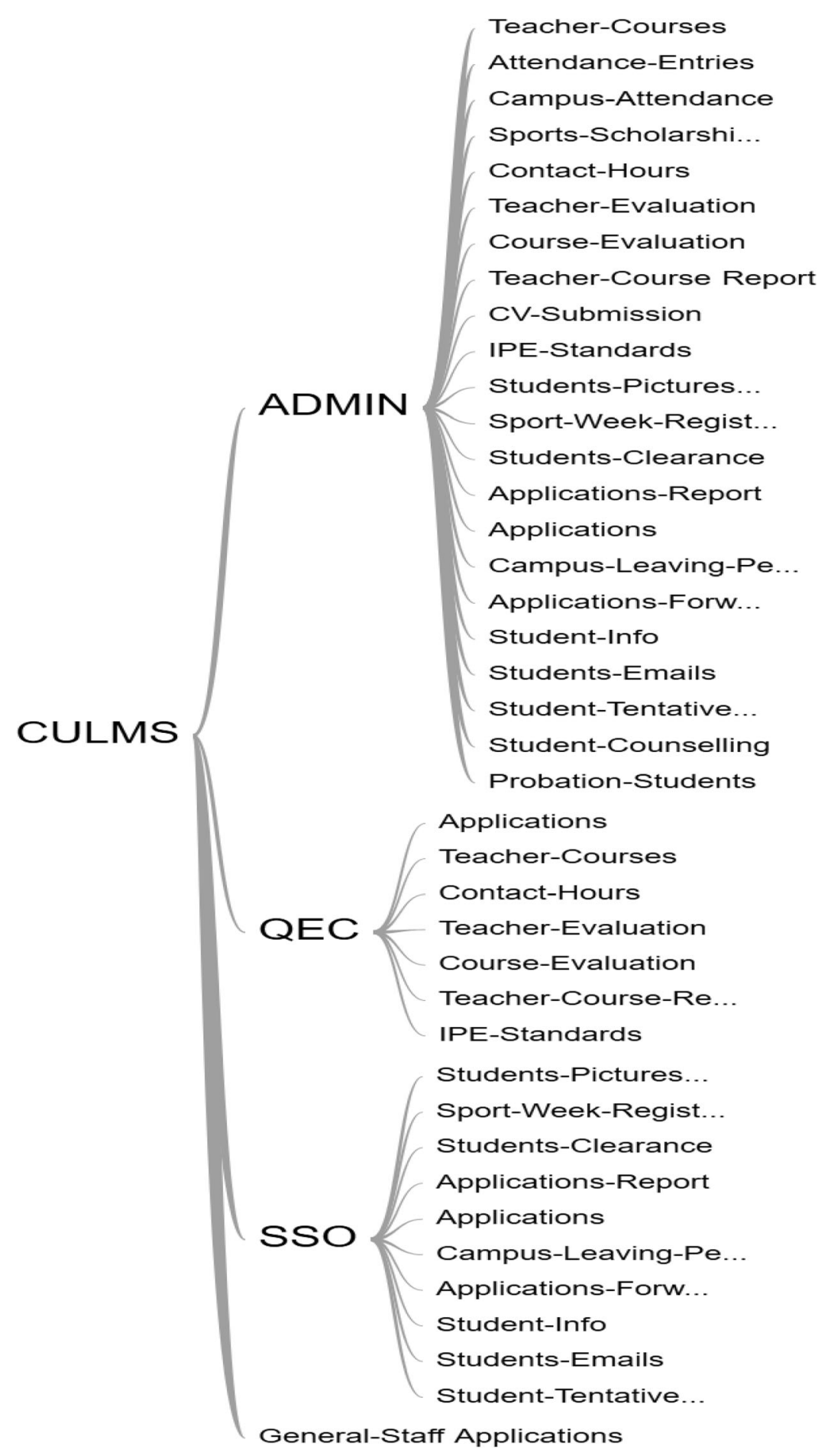

Fig. 7 Admin Staff Role in CULMS 
alternate mediums. Whereas, the HEIs are not fully equipped with the ICT enabled infrastructure to support the online education. Hence, LMS plays key role in providing solution in this current scenario. The results and findings of this study provides grounds for acknowledging the need of ICT driven HEIs with a fully functional LMS and digital infrastructure.

\section{Conclusion}

This study is conducted to understand and evaluate the digitalization of entire education system in CUSIT. The success of technological adaptation in HEIs depends on integrative effort of management, faculty, and students. The case study of CUSIT elaborates the automation of HEIs which is very important for quality education. It is found that the modern technology, management systems and ICT are essential for learning and administration of various activities in higher education. It is an encouraging sign for other universities in Pakistan as well as in developing countries that MIS, LMS, and digital campuses are probable in this part of the world. The findings of this case present an inhouse system that supports every department in performing their duties, monitoring, decision making and integrating the whole system. Although, there are evidences that the system is not utilized to its full capacity, despite this fact, it is a positive sign that system has the capacity to be utilized further. Operationally, the system is capable to be modified and augmented as per requirement to be improved further. However, there are few external factors (regulations of external bodies) that are restraining HEIs to become paperless, otherwise, these institutions would have been an environment friendly and fully digitalized. The management of HEIs need to work on overcoming the limitations (as nine limitations were identified in this study of CUSIT) and ensure that the system is fully equipped and functional to provide online education during the pandemic outbreak e.g. Covid19. Moreover, this study supports and recommends that ICT driven infrastructure shall be established for fulfilling the needs of current era as well as take an advantage of the technological advancements.

\section{Recommendations}

Based on the findings of this research, following are some of the recommendations for CUSIT as well as HEIs;

1. The functions and features of the MIS and LMS that are unutilized can be identified, followed by establishing a plan of action to make the system more efficient.

2. A comprehensive training program for all stakeholders can increase the productivity, learning and knowledge sharing abilities of the system. Capacity building is important to ensure successful implementation of system.

3. Simplification of processes and systems can increase the acceptability and dependency on digital infrastructure. This can be achieved through flexibility and 
reengineering of the system in order to avoid duplication and unnecessary overflow of information.

4. Periodic review of the existing system is important for continuous improvement of implementation as well as for adapting global trends.

5. While planning and periodic review, an input from faculty and students may help in improving the learning management system. As they are key stakeholders in academia, therefore, their feedback/suggestion can enable the system to be more comprehensive and effective.

\section{Limitations and future directions}

The findings of this study emanate from a single case study and is qualitative in nature, therefore, the results are limited on generalizability. Although, this case might be like the cases of other HEIs and may provide an insight into system, yet, it may have limited applicability. This presents future researchers to compare the systems and features of this case with other HEIs. As the case was developed on few interviews from the top management and secondary information, thus, the perspective of faculty and students is missing. Future studies may include all stakeholders in their research studies to present a broader picture. There are possibilities to conduct comparative studies as well as cross-sectional studies in the similar areas.

Acknowledgements We would like to acknowledge the support and keen interest of Mr. Muhammad Sabur Sehti, President of City University of Science and Information Technology, Peshawar Pakistan. Moreover, the technical support and data provided by I. T section of CUSIT.

Authors' Contribution Dr. Muhammad Nauman Habib has major contribution in writing introduction, building case, data collection (both primary and secondary), analysis and drafting. Dr. Waseef Jamal contributed in introduction/background of the study, analysis, tabulation of results and designing figures. Ms. Uzma Khalil contributed in data collection, drafting, proofreading and introduction.

\section{Compliance with ethical standards}

Funding This study was self-sponsored and authors did not receive any financial aid/grand from any organization for this study.

Competing interests Authors declare that there is no competing interests of any of the authors of this manuscript (neither financial nor non-financial). Although Dr. Muhammad Nauman Habib and Ms. Uzma Khalil are currently employed in the City University of Science and Information Technology (the organization under discussion in this study), however, this study will not affect their relationship with the university nor will give them any benefit/harm. Therefore, authors declare that there are no competing interests of any of the authors.

Availability of data and material The datasets generated and/or analysed during the current study are not publicly available because data was collected through interview and secondary data was collected from the IT Section in the form of reports (Excel format) but are available from the corresponding author on reasonable request. Not applicable.

Code availability Not Applicable. 


\section{References}

Agarwal, P. (2007). Higher education in India: Growth, concerns and change agenda. Higher Education Quarterly, 61(2), 197-207.

Agbatogun, A. O. (2013). Interactive digital technologies' use in southwest Nigerian universities. Educational Technology Research and Development, 61(2), 333-357.

Agyepong, I. A., \& Adjei, S. (2008). Public social policy development and implementation: A case study of the Ghana National Health Insurance scheme. Health Policy and Planning, 23(2), 150-160.

Al-Busaidi, K. A., \& Al-Shihi, H. (2010). Instructors' acceptance of learning management systems: A theoretical framework. Communications of the IBIMA, 2010(2010), 1-10.

Almeida, C., Travassos, C., Porto, S., \& Labra, M. E. (2000). Health sector reform in Brazil: A case study of inequity. International Journal of Health Services, 30(1), 129-162.

Altamony, H., Masa'deh, R., Alshurideh, M., \& Obeidat, B. (2012). Information systems for competitive advantage: Implementation of an organisational strategic management process. Paper presented at the proceedings of the 18th IBIMA conference on innovation and sustainable economic competitive advantage: From regional development to world economic, Istanbul, Turkey, 9th-10th May.

Altbach, P. G. (1999). Private Prometheus: Private higher education and development in the 21st century (Vol. 77). Westport: Greenwood Publishing Group.

Amassoma, D. J., Ayanda, D. O., \& Tijani, K. (2010). Internet usage among Nigerian polytechnic students and its impact on manpower development: A case study approach. Journal of Information Technology Impact, 10(3), 161-170.

Anshari, M., Alas, Y., \& Guan, L. S. (2016). Developing online learning resources: Big data, social networks, and cloud computing to support pervasive knowledge. Education and Information Technologies, 21(6), 1663-1677.

Arkorful, V., \& Abaidoo, N. (2015). The role of e-learning, advantages and disadvantages of its adoption in higher education. International Journal of Instructional Technology and Distance Learning, 12(1), 2942.

Aziz, M., Bloom, D. E., Humair, S., Jimenez, E., Rosenberg, L., \& Sathar, Z. (2014). Education system reform in Pakistan: why, when, and how? Bonn: IZA Policy Paper.

Bakari, J. K., Tarimo, C. N., Yngstrom, L., \& Magnusson, C. (2005). State of ICT security management in the institutions of higher learning in developing countries: Tanzania case study. Paper presented at the fifth IEEE international conference on advanced learning technologies (ICALT'05).

Barak, M., Lipson, A., \& Lerman, S. (2006). Wireless laptops as means for promoting active learning in large lecture halls. Journal of Research on Technology in Education, 38(3), 245-263.

Barron, A. E. (2003). Course management systems and online teaching. Journal of Computing in Higher Education, 15(1), 128-142.

Baxter, P., \& Jack, S. (2008). Qualitative case study methodology: Study design and implementation for novice researchers, The Qualitative Report, 13(4), 544-559.

Browne, T., Jenkins, M., \& Walker, R. (2006). A longitudinal perspective regarding the use of VLEs by higher education institutions in the United Kingdom. Interactive Learning Environments, 14(2), 177-192.

Capper, J. (2003). Complexities and challenges of integrating technology into the curriculum. TechKnowLogia, 5(1), 60-63.

Charmaz, K. (2008). Constructionism and the grounded theory method. Handbook of Constructionist Research, 1, 397-412.

Cohen, L., Manion, L., \& Morrison, K. (2013). Research Methods in Education. Routledge.

Creswell, J. W. (2013). Research design: Qualitative, quantitative, and mixed methods approaches. Sage Publications.

Etikan, I., Musa, S. A., \& Alkassim, R. S. (2016). Comparison of convenience sampling and purposive sampling. American Journal of Theoretical and Applied Statistics, 5(1), 1-4.

Farid, S., Ahmad, R., Niaz, I. A., Arif, M., Shamshirband, S., \& Khattak, M. D. (2015). Identification and prioritization of critical issues for the promotion of e-learning in Pakistan. Computers in Human Behavior, 51, 161-171.

$\mathrm{Fu}, \mathrm{X}$. (2012). The influences of budgetary system in a selection of large Chinese companies in the industry of electronic household appliances. Durham University.

Gibbone, A., Rukavina, P., \& Silverman, S. (2010). Technology integration in secondary physical education: Teachers' attitudes and practice. Journal of Educational Technology Development and Exchange (JETDE), 3(1), 3 . 
Gourley, W. (2009). Conceptualising the Interface between english further and higher education. University of Sheffield: Doctoral dissertation.

Habib, M. N., Jamal, W., \& Manzoor, H. (2019). Mapping public sector reforms through thematic networks: A case of computerized driving licensing authority, Khyber Pakhtunkhwa. Abasyn University Journal of Social Sciences, 12(2), 298-322.

Halai, N. (2013). Quality of private universities in Pakistan: An analysis of higher education commission rankings 2012. International Journal of Educational Management, 27(7), 775-786.

HEC. (2019). HEC recognised universities and degree awarding institutions. Retrieved 25-03-2019, 2019.

Hennessy, S., Ruthven, K., \& Brindley, S. (2005). Teacher perspectives on integrating ICT into subject teaching: Commitment, constraints, caution, and change. Journal of Curriculum Studies, 37(2), 155-192.

Khan, A. (2007). The education system and prospects for e-learning in Pakistan. End-to-End eLearning. Stockholm: Stockholm College.

Kukulska-Hulme, A., \& Traxler, J. (2007). Mobile teaching and learning. In A. Kukulska-Hulme \& J. Traxler (Eds.), Mobile learning: A handbook for educators and trainers. New York: Routledge.

Mostert, M., \& Quinn, L. (2009). Using ICTs in teaching and learning: Reflections on professional development of academic staff. International Journal of Education and Development using ICT, 5(5), $72-84$.

Mukama, E., \& Andersson, S. B. (2008). Coping with change in ICT-based learning environments: Newly qualified Rwandan teachers' reflections. Journal of Computer Assisted Learning, 24(2), 156-166.

Mwalongo, A. (2012). Teachers' perceptions about ICTs for teaching, professional development, administration and personal use. International Journal of Education and Development using ICT, 7(3), 36-49.

Nowell, L. S., Norris, J. M., White, D. E., \& Moules, N. J. (2017). Thematic analysis: Striving to meet the trustworthiness criteria. International Journal of Qualitative Methods, 16(1), 1-13.

Patterson, R. W., \& Patterson, R. M. (2017). Computers and productivity: Evidence from laptop use in the college classroom. Economics of Education Review, 57, 66-79.

Qureshi, I. A., Ilyas, K., Yasmin, R., \& Whitty, M. (2012). Challenges of implementing e-learning in a Pakistani university. Knowledge Management \& E-Learning, 4(3), 310.

Rezaei, S., \& Meshkatian, M. A. (2017). Iranian teachers' attitude towards using social media and technology to increase interaction amongst students inside or outside the classroom. Theory and Practice in Language Studies, 7(6), 419-426.

Rhode, J., Richter, S., Gowen, P., Miller, T., \& Wills, C. (2017). Understanding faculty use of the learning management system. Online Learning, 21(3), 68-86.

Rizwan, M., Azad, Z., Ali, A., \& Mahmood, S. (2016). Comparative study on educational management in public and private institutions in the twin cities of Pakistan. Research on Education and Media, 8(2), 5159.

Ruthven, K., \& Hennessy, S. (2002). A practitioner model of the use of computer-based tools and resources to support mathematics teaching and learning. Educational Studies in Mathematics, 49(1), 47-88.

Sanders, M., \& George, A. (2017). Viewing the changing world of educational technology from a different perspective: Present realities, past lessons, and future possibilities. Education and Information Technologies, 22(6), 2915-2933.

Sani, A., \& Tiamiyu, M. (2005). Evaluation of automated services in Nigerian universities. The Electronic Library, 23(3), 274-288.

Sarkar, S. (2012). The role of information and communication technology (ICT) in higher education for the 21 st century. Science, 1(1), 30-41.

Sife, A., Lwoga, E., \& Sanga, C. (2007). New technologies for teaching and learning: Challenges for higher learning institutions in developing countries. International Journal of Education and Development using ICT, 3(2), 57-67.

Soni, V. (2000). A twenty-first-century reception for diversity in the public sector: a case study. Public Administration Review, 60(5), 395-408.

Soomro, S., Soomro, A. B., Bhatti, T., \& Ali, N. I. (2018). Implementation of blended learning in teaching at the higher education institutions of Pakistan. International Journal of Advanced Computer Science and Applications, 9(8), 259-264.

Ssekakubo, G., Suleman, H., \& Marsden, G. (2011). Issues of adoption: have e-learning management systems fulfilled their potential in developing countries? Paper presented at the proceedings of the South African Institute of computer scientists and information technologists conference on knowledge, innovation and leadership in a diverse, multidisciplinary environment.

Sweeney, J., O'donoghue, T., \& Whitehead, C. (2004). Traditional face-to-face and web-based tutorials: A study of university students' perspectives on the roles of tutorial participants. Teaching in Higher Education, 9(3), 311-323. 
Tierney, W., \& Sirat, M. (2008). Challenges facing Malaysian higher education. International Higher Education, 53, 23-24.

Tolley, H., \& Shulruf, B. (2009). From data to knowledge: The interaction between data management systems in educational institutions and the delivery of quality education. Computers \& Education, 53(4), 11991206.

Tongco, M. D. C. (2007). Purposive sampling as a tool for informant selection. Ethnobotany Research and Applications, 5, 147-158.

Uddin, S., \& Tsamenyi, M. (2005). Public sector reforms and the public interest: a case study of accounting control changes and performance monitoring in a Ghanaian state-owned enterprise. Accounting, Auditing \& Accountability Journal, 18(5), 648-674.

Wabwoba, F., Omieno, K., Simiyu, C., \& Sisungo, Z. (2011). The role of wireless technologies in taking education to rural villages in developing countries. International Journal of Information and Communication Technology Research, 1(7), 300-305.

Wheeler, S. (2001). Information and communication technologies and the changing role of the teacher. Journal of Educational Media, 26(1), 7-17.

Yin, R. K. (2003). Case study research: Design and methods (3rd ed.). Thousand Oaks, CA: Sage.

Publisher's note Springer Nature remains neutral with regard to jurisdictional claims in published maps and institutional affiliations.

\section{Affiliations}

\section{Muhammad Nauman Habib ${ }^{1}$ - Waseef Jamal ${ }^{2}$ • Uzma Khalil ${ }^{3} \cdot$ Zunnoorain Khan $^{1}$}

Waseef Jamal

Waseef.jamal@imsciences.edu.pk

Uzma Khalil

enigmaticuzma@yahoo.com

Zunnoorain Khan

zunnoorain@cusit.edu.pk

1 Department of Management Sciences, City University of Science and Information Technology, Peshawar, Pakistan

2 Institute of Management Sciences, Peshawar, Pakistan

3 Department of English, City University of Science and Information Technology, Peshawar, Pakistan 